\title{
MENCARI FORMAT IDEAL TEO-EKOLOGI DARI HUBUNGAN ANTAR AGAMA DAN SAINS
}

\author{
Oleh: Baedbowi*
}

\section{Abstract:}

This article attempts to describe the frame-2yorks and approaches of science and religion. Although both of these disciplines are difference in gaining their main goals, they bave not to be opposite in dichotomies. The oppositions of scientific and religious thought bave become a secularist civilization and have made some crisis. One of them is an ecological crisis. We can show relationship between science and religion in two models: both science and religion bave difference methodology and approach; Science and Religion bave same apparel or similar methodology and approach. In the last model, scientific and religious views can be barmonized to build a new perspective of theology. From these views, the writer tries to show, and to developed mutual dialogue and integration of science and religion and to explore the urgency or significant meaning of process theology as a new Theo-ecology, especially in Islamic thought.

\section{نحالوصة}

تحاول هذه المقالة وصف الأطر المفاهيمية والاقترابات الحناصة بكل من الدين والعلم؛ متوحلة إلى أن لكل منهما طريقه في تحقيق أهدافه، إلا إنما ليما طرفي نقيض، بل إن وضع أحدها في مقابل الآخر قد أدى لقيام حضارة علمانية مأزومة، وإحلى أزمات تلك الحضارة هي الأزمة البيئية. تظهر المقالة الحالية العلاقة بين الدين والعلم من خحالل أنموذجين؛ الأول: حيث يمتلك كل منهما منهجية واقترابات مختلفة، والآخر: حيث يمتلك كل منهما منهجية واقترابات متشاهية. وفي الأكموذج الأخحير تتناغم الرؤى الدينية والعلمية نيخو بناء منظورات دينية علمية جديدة. ومن خلال تلك المنظورات يطمح الكاتب إلى تطوير حوار متكامل بين العلم والدين مع استكشاف دلالاته في مضمار الأزمة البيئية الحالية.

Keywords: Agama, Sains, Proses dialog-integratif, Teo-ekologi

- Dosen dan Peneliti di STAINU, Temanggung, Jawa Tengah 


\section{A. Pendabuluan}

Berbagai bencana alam yang telah menimpa negeri ini seperti banjir di ibukota Jakarta dan daerah lain, tanah longsor, kebakaran hutan, tsunami di Aceh dan Pengandaran, gempa bumi di Yogyakarta dan Manado, serta di daerah lain telah menjadi catatan sejarah tragedi bencana nasional. Belum lagi dalam skala global, manusia juga dihadapkan oleh keadaan lingkungan yang sangat serius dan mengancam keselamatan hidup manusia, misalnya seperti jebolnya lapisan ozon di atas Kutub Selatan, naiknya permukaan air laut, turunnya hujan asam, naiknya suhu udara, dan kacaunya iklim. Semua perubahan alam itu telah menimbulkan berbagai penafsitan dan kegelisahan tersendiri bagi kalangan ilmuwan maupun agamawan. Para ilmuwan biasanya akan tertarik dengan peristiwa bencana itu dari sisi fenomena alam dan perubahan-perubahan yang ditimbulkannya. Sementara para agamawan akan menjustifikasi peristiwa bencana tersebut sebagai campur tangan Tuhan atas prilaku-prilaku penyimpanagan dan kesemenaan ulah manusia atas eksploitasi alam. Ilmuan (fisikawan) lebih tertarik dari sisi verifikasi atas fenomena alam dan perubahannya sedangkan agamawan biasanya lebih tettarik dengan sisi campur tangan Tuhan atas dosa-dosa manusia sebagai penghuni, penjaga, dan pewaris alam.

Hanya saja bila wilayah ilmuan dan agamawan tidak terjembatani akan memunculkan ketegangan dan berlarutnya klaim kebenaran atas masing-masing wilayah penafsiran. Ketegangan hubungan antar agama dan sains, tampaknya juga tidak pernah selesai. Hal ini bukan saja karena dasar epistemologisnya yang berbeda, namun juga dikarenakan cara melerai ketegangan itu. Para ilmwuan dan filosof muslim memang pernah terlibat dalam ketegangan ini dan melerai ketegangan tersebut ketika agama harus berhadapan dengan filsafat Yunani, akhirnya mereka justru bisa memberi pencerahan di dalamnya.

Dari gambaran di atas, setidaknya Islam memang dari awal tidak ingin memisahkan hubungan antara agama dan sains, yang di dunia Barat modern dikenal sekularisasi. Hanya saja ketika dunia Islam dilampaui oleh Barat oleh berbagai kemenangan dalam sains, akhirnya dialog dan integrasi agama dan sains ditasa semakin mendesak dan perlu. Abad ke 19 dan 20, ketegangan itu tampaknya muncul dan menguat kembali ketika agama ingin memberi tespon terhadap sains. Akibatnya, kita bisa memahami ketika saintis seperti embriolog, Perancis semacam Mourice Baucaille untuk sementara waktu dianggap bisa melerai dan "memuaskan" kaum saintis dan agamwan dengan mencoba membuktikan keserasian Kitab Suci (Bibel dan al-Quran) dengan sains tanpa bermaksud apologis. ${ }^{1}$ Pembuktian yang tanpa melihat berbagai ketegangan relasi antara kedua wilayah ini yang sering dipopuletkan

'Lihat Mourice Boucaille (1981), Le Coran le Bible et la Science, Paris: Saghers. 
dengan Buchailianisme.

Meskipun di dunia Muslim dari dulu tidak ada maksud untuk memisahkan agama dan sains, akhit-akhir ini kerinduan untuk mengharmoniskan kembali relasi agama dan sains tampak menguat kembali dengan munculnya berbagai temuantemuan mutakhir, di bidang neurologis, fisika, dan kedokteran. Orang-orang semacam A.N.Whithehead, Ian Barbour (mewakili pandangan Kristiani) atau SH Nast dan Ziauddin Sardar (mewakili Islam) dengan penekanan yang berbeda merupakan ilmuan-teolog-spiritualis yang berusaha memberi masukan positif tentang idealisasi hubungan agama dan sains. Hanya saja ketika Nasr ingin mencoba memasukan pandangan metafisis (baca filsafat perenial) secara berlebihan atau ketika obsesi Sardar hendak merealisasikan Islamisasi sains, seolah-olah mereka telah melampaui porsi kajian yang semestinya. Nasr tampak terkesan konservatif dan Satdar terkesan -apologis, meskipun kritik mereka atas ideologi sains modern dan masukan-masukan mereka dalam etika dan spiritualitas säins untuk konteks kontemporer juga sangat perlu dipethatikan ditengah semakin destruktifnya perilaku mamusia modern terhadap alam dan lingkungannya..

Sebagai muslim penulis justru lebih bersimpati pada sosok Abdus Salam, peraih hadiah Nobel Fisika pada tahun 1970. Dia tanpa berambisi mengislamkan atau mensipiritualisasikan sains justru berkarya secara totalitas dengan spesialisasi dan keyakinannya. Dengan cara itu, Salam justru telah membuktikan ilmunya secara praksis. Sebagai muslim dia berpandangan, bahwa tafakkur, yakni berefleksi, berpikir dan menemukan hukum-hukum alam (sains) dan tasykir, yakni memperoleh penguasaan atas alam (dengan teknologi), keduanya merupakan dorongan-dorongan terpadu seluruh umat manusia di sepanjang zaman. Sebagai bukti keagungan Islam, Al-Qur'an sejak dini telah berulang kali menyuruh manusia untuk bertafakur dan ber-tasykir (mengejar sains dan teknologi) sebagai kewajiban bagi masyarakat Muslim. ${ }^{2}$

Dari pandangan “ilmuan-teolog” semacam itu, jika kemungkinan konflik memang diakui dalam relasi Agama dan sains, maka yang perlu dibenahi kembali adalah mengenali sumber masing-masing wilayah. Bila ada keyakinan bahwa Kitab Suci (agama) dan Kitab Alam (sains) keduanya berasal dari Tuhan Yang Satu, analisis masing-masing seharusnya menunjukkan bahwa keduanya tidak ada konflik antat dua kebenaran dari sumber yang sama. Caranya tentu dengan memodifikasikan tafsiran filosofis atas teori ilmiah ataupun dengan merevisi kajian teologisnya. ${ }^{2}$ Dalam

${ }^{2}$ Abdus Salam, Panji Masyarakat, No. 400., p. 21. Sebagai Muslim Salam di era 60-an bersama Weinberg dan Glashow juga telah mengembangkan "teori medan gabungan" (unified field theory), teori yang menyatakan bahwa semua gaya yang ada di dunia ini berasal dari satu single force, bahwa pada saat terjadi The Big Bang, kira-kira 15 milyar tahun yang lalu saat gaya elektromagnetik pernah berpadu dengan gaya nuklir lemah. Tahun 1983 tim yang dipimpin oleh Carlo Rubbia dari Harvard University juga telah membuktikan kebenatan teori Abdus Salam dengan penemuan partikel "W" dan " $Z$ ". 
pada premis di luar disiplinnya. Misalnya anggapan bahwa sains hanya berurusan dengan fakta dan deskripsi tentang alam sementata urusan agama adalah soal dogma dan makna. Dengan ini keduanya terpisah sama sekali dan konflik tidak akan terjadi. ${ }^{7}$

Denis Carol, seorang filosuf dan teologi modetn juga berupaya meredam ketegangan yang terjadi antara agama dan sains. Menurutnya diperlukan adanya suatu pendekatan agama (teologi) yang mampu mengambil manfaat dari pandanganpandangan ilmiah karena sains sebetulnya tidak memiliki paradigma yang membahayakan norma agama. Manusialah yang membuat interpretasi terhadap temuan-temuan ilmu. Teologi harus mampu mengambil manfaat dari hasil temuan ilmiah yang ada. Konsepsi Carol kemudian dinyatakan sebagai "teologi pembebasan".8

Ketegangan antar sains dan agama tampaknya semakin terdamaikan dengan upaya pendekatan Ian Barbour yang lebih bersipati kepada pendekatan Dialog dan Integrasi, meskipun sebelumnya ia hanya lebih bersimpati pada pendekatan Integrasi. Upaya Barbour ini dengan karya-karyanya selain memberikan peta bagi pengembangan sains dan agama juga memberikan keleluasaan masing-masing ilmuan (agamawan dan saintis) untuk bisa mengekplorasi spesialisasinya tanpa perlu mengoposisikan secara biner antara kebenaran agama dan sains. Upaya keras Boarbour dalam membangun "theology of nature" dalam makna terluasnya akhirnya juga mengimbas pada "murid-murid" dan para sarjana terkemuka, seperti William James, Neils Bohr, Sayyed Hussein Nasr, Annemarie Schimmel, Sallie Mc-Fague dan ilmuan lainya. Mc-Fague bahkan menegaskan bahwa Barbour bagi para teolog adalah sahabat yang mengajarkan perkembangan mutakhir sains dan Implikasi metafisisnya. Sementara bagi ilmuan ia menunjukkan relevansi teologis dengan teori-teori ilmiah. ${ }^{9}$ Pernyataan semacam inilah tampaknya juga semakin memantapkan secara psikologis masing-masing ilmuan untuk terus maju berkarya tanpa beban teologis.

Upaya yang ditempuh Carol atau Barbour di atas patut dihargai sebagai sebuah idealisasi teologi yang mempunyai watak lembut atau sebagai upaya harmonisasi antar sains dan agama yang dapat mengeliminir ketegangan-ketegangan. Dengan upaya semacam itu, paling tidak bisa memberi nuansa teologi yang berwatak humanis dan ramah lingkungan.

3. Bagaimana model ideal relasi agama dan sains ?

Dalam Teologi Filsafat (Pbilosopbycal Theology) teolog-ilmuan ingin membangun pengetahuan tentang kebenaran (Tuhan) yang berpangkal dari pengalamanpengalaman atau temuan-temuan manusia tentang kealaman atau dikenal sebagai

${ }^{7}$ Lihat Barbour, Op. Cit. Terutama uraiannya tentang pendekatan Konflik dan Independensi.

${ }^{8}$ Denis Carol, What is Liberation Theology (tth), Sydna: E.J. Dawyer, p. 24.

'Baqir, "Pengantar", pp. 24-25. Juga Barbour, Op. Cit., p. 40 dst. 
man's natural light. Kerangka kerja teologi semacam ini merupakan man's mouvement toward God. ${ }^{10}$ Proses bertafakkur semacam ini (meminjam istilah Abdus Salam di atas) dalam artian membaca ayah al-kauniah atau tadabbur alatn juga sangat dianjurkan dalam Islam (Qur'an-Sunnah). Bahkan makna ayat sendiri dalam literatur arab juga selalu dikaitkan dengan konteks Ke-Esaan Tuhan (tauhid). Terlepas dari apa nama dan jenis teologi, penulis melihat bahwa memang ada perbedaan pandangan tentang relasi agama (teologi) dan sains di abad modern, atau dengan kata lain sains lebih berurusan dengan persoalan "fakta", sementara agama lebih berkaitan dengan persoalan "makna". Karena itu, kalau dalam sisi pendekatan hubungan agama dan sains Ian Barbour menawarkan empat pendekatan, yakni konflik, independen dialog dan interegrasi, ${ }^{11}$ maka dari pendekatan ini Batbour mensinyalir ada tiga pandangan utama: pertama, bahwa agama tidak sejalan dengan sains, Kedua, agama sejalan dan seirama dengan sains, Ketiga, agama (keimanan, teologi) mendapat masukan dan kontribusi positif dari ilmu pengetahuan.

a) Antara agama dan sains betbeda sama sekali

Pandangan seperti ini, berpangkal pada pemikiran yang melihat sains secara positivistik sebagai sebuah upaya yang menghasilkan pengetahuan teknis positif yang berbeda dengan konklusi-konklusi agama (teologis) secara luas. Dalam pandangan ini, bahwa metode-metode sains secara radikal berbeda dengan metode agama. Keduanya harus terpisah dan independen. Tidak hanya isi dan subyect matternya yang tidak berkaitan, tetapi cara mendapatkan kebenarannyapun berbeda. Karena itu, konflik antara keduanya tidak mungkin terjadi karena isu yang dibicarakan di dalamnya dirancang untuk masing-masing bukan keduanya secara betsamaan. Meskipun begitu, keduanya dapat memberi kontribusi satu sama lain. Titik bahasan teologi bukan metupakan kajian ilmu pengetahuan, salah satunya tidak dapat diakses oleh yang lain. Sebaliknya, sains juga bukan rumusan dogma yang harus dipertahankan secara mati-matian. Adapun konflik yang pernah terjadi lebih karena kegagalan dalam memahami perbedaan yang ada. ${ }^{12}$

Dalam pandangan yang semacam ini, antara lain tetdapat golongan: NeoOrtodoksi dan Analisis Linguistik. Golongan pertama menekankan pertentangan antar wahyu dan temuan manusia. Sedangkan golongan kedua lebih menekankan pada pentingnya memahami pemakaian bahasa. Karena memang terdapat alasan untuk menunjukkan keterputusan antar konsep teologis dan sains. Menurut kelompok Neo-Ortodoksi, tipikal wahyu itu sendiri yang sejatinya membedakan dirinya dari penemuan-penemuan manusia. Sedangkan menurut golongan Analisis Linguistik,

${ }^{10}$ Lihat L. Muller, ed. (1972), God and Reason: A Historical Approach to Pbiloshopycal Theology, New York: The MacMillan Company, p. 12.

${ }^{11}$ Lihat Barbour, Op. Cit.

${ }^{12}$ Ian Barbour (1966), Issues in Science and Religion, USA: Prentice-Hall, Inc., p. 116 
titik perbedaannya justru terletak pada fungsi bahasa agama dan sains yang memang berbeda. Hanya saja untuk konteks pengembangan PTAI (Perguruan Tinggi Agama Islam) di Indonesia menurut hemat penulis pendekatan seperti disebut di atas justru akan semakin membuat kesenjangan dalam dialog dan integrasi antara agama dan sains.

b) Agama sejalan dan pararel dengan sains

Pandangan lainnya melihat adanya kesamaan metodologis antara agama dan sains dalam melihat kebenaran. Kesamaan itu terdapat pada struktur dan bukan materi, karena keduanya memiliki materi masing-masing yang independen. Ada dua golongan yang termasuk dalam kategori pemikiran ini: pertama, golongan pemikitan agama (teologi) liberal (liberal theology). Kedua, golongan filsafat proses (process philosbopy).

1) Kelompok teologi liberal

Golongan ini mengasumsikan kesamaan prinsip pencatian informasi keagamaan dengan kesamaan prinsip penemuan sains. Menurut mereka, keyakinan keagamaan seseorang seharusnya merupakan interpretasi yang logis pada wilayahwilayah pengalaman kemanusiaan dengan menggunakan pikitan kritis sebagaimana para ilmuan dalam kerja ilmiahnya. Jadi Agama (teologi) harus bersifat ilmiah dalam arti tasional-empiris, terbuka (openness) dan bersifat sementara (tentativeness) yang bisa diterapkan oleh ilmuan pasti juga bisa diterapkan teolog. ${ }^{13}$

Mengenai konsep wahyu, kelompok teolog liberal ini menggunakan dua cata interpretasi. Pertama, dengan mengeliminir keunikan wahyu. Cara tersebut didasari atas asumsi bahwa Tuhan menstransmisikan wahyunya melalui beragam cara: misalnya sesuai dengan strukrut makhluk, sesuai dengan kesadaran moral manusia dan tradisi keagamaan umum yang beraneka ragam. Kedua, dengan mengapresiasikan secara positif-simultan temuan manusia. Cara ini berangkat dari asumsi bahwa wahyu turun pada manusia untuk dipahami dan tidak mustahil manusia mendistorsi makna-makna dari wahyu tersebut lantaran keterbatasan pemahaman yang ada padanya.

Mazhab teologi liberal tersebut tampak lebih menekankan aspek imanensi Tuhan daripada transendensinya. Berbeda dari golognan teologi liberal, golongan Neo-ortodoksi menekankan pada konsep keterputusan, sementara kelompok liberalisme meyakini terhadap ketersambungan wahyu dan akal, keyakinan dan pengalaman manusia, Tuhan dan dunia, serta Kristen dan agama yang lain. Dari konsep semacam itu, bisa dipahami bila guru besar Islamic Studies di universitas Sorbonne Nouveklle (Paris III), Mohammed Arkoun memaknai dan menterjemahkan wahyu sebagai kebenaran ilahiah yang secara kongkrit akan termanifestasikan dalam 
realitas sejarah (Revelation $=$ Verite - realite bistorique) ${ }^{14}$

2) Aliran filsafat proses

Golongan ini mencoba mengembangkan sistem metafisika yang dapat diaplikasikan ke semua aspek realitas yang meliputi Tuhan dan kejadian-kejadian historis di dunia ini. Kelompok ini dapat kritis terhadap pandangan positivisme sains. Tokoh yang berjasa mensosialisasikan pandangan ini adalah Alfred Nort Whitehead, juga Holmes Rolston. Whitehead berjasa membangun wacana metafisika dan filsafat ilmu sehingga dapat memunculkan bangunan sistem ide yang membawa kepentingan-kepentingan agama, moral, estetika kedalam sebuah hubungan dengan penerapan konsep-konsep dunia yang berasal dari ilmu alam. ${ }^{14}$ Whitehead berpandangan bahwa metafisika merupakan pemahaman karakteristik kejadian yang paling umum. Metafisika lazim bersifat koheren dan relevan dengan alam empirik. Dari pemahaman semacam itu, alam selalu mengembangkan bukti dan evidensi independensinya yang kemudian dideskripsikan oleh metafisika. ${ }^{15}$

Ada tiga prinsip pokok dalam filsafat proses. Pertama, prinsip keunggulan waktu (the primecy of time). Artinya, bahwa dunia merupakan sebuah proses menjadi ( a proses of becoming ). Ia merupakan sebuah akumulasi kejadian. Aktifitas dan transisi lebih urgen daripada substansi atau permanensi. Kedua prinsip keterkaitan antara kejadian-kejadian. Bahwasanya dunia dipahami sebagai rangakain kejadian-kejadian berangkai dan menjadi jaringan sebuah sruktur jaringan yang kohesif. Ketiga adalah prinsip organisme, dalam pengertian bahwa realitas ini dilihat sebagai proses organik. ${ }^{16}$

Berangkat dari pandangan itu, Whitehead melihat agama seharusnya bersifat progresif, termasuk di dalamnya adalah konsep teologi seiring dengan pandangan kosmologi yang berproses secara organis. Menurut pengamatannya atas sejarah sains dan agama, pengaruh agama-agama dalam kehidupan manusia dewasa ini, tidak sekuat dan seefektif seperti masa-masa lalu. Agama-agama itu menurutnya telah kehilangan daya cengkram atau pengaruhnya atas dunia, "they bave lost their ancient bold upon their world'17

${ }^{14}$ Lihat Mohammed. Arkoun, et. al. (1990), Liberte Religious dans le Judaisme, le Christianisme et IIslam, Paris:CERF, pp. 110-111. Juga Mohammed Arkoun (1993), "Le Concept des Societes du LivreIivre” dalam Interpreter, No. 3, p. 213. Dalam konteks teologi Islam pandangan Mohammad Iqbal atau Mohammed Arkoun, hemat penulis bisa dimasukkan dalam kelompok ini, Lihat, Mohammad Iqbal (1977), Reconstruction of Religious Thought in Islam, Lahore: M. Asraf, Juga Mohammed. Arkoun (1991), Lectures $d u$ Coran, ed. Tunis: Alif.

${ }^{1+}$ Alfred N. Whitehead (1929), Proces and Reality, New York: The Macmillan . Co, p. vi. Lihat juga Holme Rolston (1987), Science and Religion, A Critical Survey, New York : Random Housse, pp. 398-399.

${ }^{15}$ Barbour, Op. Cit., p. 128

${ }^{16} \mathrm{Ibid}, \mathrm{p} .129$

${ }^{17}$ Alfred N. Whitehead (1974), Religion in the Making, New York: New American Literary, Pernyataan Whitehead di atas didasari atas hsitorisitas dunia Eropa dan Amerika ini muncul di tahun 1925. 
Kemerosotan agama-agama tersebut menurutnya disebabkan oleh dua hal. Pertama, adanya stagnasi atau kemandegan yang berujung pada sikap konservatisme dan difensif terhadap segala perubahan yang disebabkan oleh perkembangan sains dan teknologi. ${ }^{18}$ Kedua, ketidaksesuaian antara gambaran tentang Tuhan yang secara tradisional cukup banyak dijelaskan oleh agama-agama yang ada dengan manusia modern. Tuhan dalam gambaran tradisional adalah bagaikan sang raja absolut yang selalu harus ditakuti. Padahal dalam gambaran dunia modern Tuhan lebih dilihat sebagai kekuasaan kasih sayang yang memberi ruang kebebasan pada manusia untuk memikul tanggung jawab pribadinya. ${ }^{19}$

Dari gambaran seperti itu, maka tidak mengherankan bila kita melihat pandangan manusia yang ambivalen terhadap posisi agama dan sains. Di satu sisi teologis banyak rekan muslim kita yang terjebak dalam pandangan yang fatalistis (model jabariab) di mana berbagai bencana alam yang terjadi di tanah air lebih dikarenakan oleh kehendak Tuhan semata atau sebagai suratan takdir. Sementata di sisi lain, dari positivisme sains banyak manusia modern bisa mengoptimalkan kemampuan sains untuk mengekpoitasi alam secara semena-mena dan destruktif demi kekayaan, kesenangan dan ambisi-ambisi pribadinya. Prilaku distruktif manusia atas alam secara ekologis ini sebagai mumi ulah dan nafsu-nafsu liar manusia, sehingga menjadi semakin jelaslah berbagai kerusakan ekologis di muka bumi (Cf. QS, 30:41). Padahal secara agama (teologis) sebenarnya bumi ini ingin diwariskan Tuhan pada hamba-hambanya yang shalih (Inna al-ardba yurisuba min ibadiya asshalihun), yakni bagi mereka yang bisa mengimbangi visi teologis dan kemampuan saintifisnya untuk kemakmuran, kesejahteraan dan kenyamanan manusia bersama.

Gambaran yang kurang responsif tentang kebaikan Tuhan tersebut pada akhirnya tidak mampu memberi motivasi pada manusia untuk bersikap aktif dinamis dalam menatap kehidupan. Wajah negatif agama semacam ini dalam konteks Islam pernah diperbaiki misalnya oleh Iqbal melalui inovasi makna Ijtihad sebagai sebuah pengupayaan proses gerak sejarah secara dinamis dalam Islam. ${ }^{20}$ Begitu juga konsepsi Fazlut Rahman tentang Tuhan dalam modernitas tampaknya selain ingin menjawab gambaran negatif Whitehead dalam visi teologis sebagai salah dalam memahami Islam (Qur'an). Rahman juga ingin menjelaskan bahwa teologi Islam juga sangat menghargai antroposentris. Karena Tuhan dalam Islam tidak seperti gambaran sarjana Barat sebagai kekuatan yang kejam layaknya "taja yang lalim" dan semena-mena (even as brute power - indeed as a carpricous tyrant). Selain itu, Rahman juga ingin menjelaskan bahwa alam dan manusia pada hakekatnya adalah muslim (tunduk pada Tuhan), bedanya manusia masih bisa mengingkari perintah-perintah-Nya sementara

\footnotetext{
${ }^{18}$ Whitehead, Op. Cit., p. 188.

${ }^{19}$ 'Whitehead, Op. Cit., p. 40.

${ }^{20}$ Lihat Iqbal, Op. Cit.
} 
alam tidak. Karena itu perintah kepada alam dalam analog manusia adalah perintah moral (pengembangan makna taqwa). ${ }^{21}$ yang di dalamnya tentu ada imperatif untuk bersikap ramah terhadap lingkungan (sesama manusia dan alam) atau sebagai penjabaran makna rabmatan li al'alamin.

Dari konsep alternatif Whitehead tentang Tuhan dalam arti sebagai filsafat proses, yang kemudian dikembangkan oleh muridnya Ch. Hartahorn ke dalam gagasan ideologi proses yang perlu ditegaskan - adalah bahwa semua yang ada ini termuat dalam Tuhan di tengah harmonisasi paduan antara aspek primordial (sifat awaliyab) dan sifat akbiriyab (consecuent)-Nya. Konsep semacam ini kemudian dikenal dengan panentheisme, ${ }^{22}$ yang dapat menjalin hubungan harmonis pandangan makrokosmis melalui perkembangan sains dan. konsep teologi. Pandangan teologi proses ini juga diteruskan oleh Barbour. Alasan praktisnya karena ia lebih sesuai dengan teori-teori sains mutakhir, khususnya yang berkaitan dengan teori-teori evolusi dan kosmolgi. ${ }^{23}$

c) Sains berkontribusi terhadap agama

Golongan ketiga ini berkeyakinan bahwa sains dapat menjadi kontributor terhadap agama (teologi). Dengan ungkapan lain bahwa konsep-konsep dan kesimpulan kesimpulan teologis terambil dari sains. Dengan demikian dalam pandangan kelompok ini, eksistensi Tuhan dapat diketahui dengan mudah melalui gambaran dan karakteristik alam secara umum seperti dalam pola dan keteraturannya, dan melalui temuan-temuan spesisifik fenomena keberlangsungan proses evolusi alam dan karakteristik fisika modern.

Karena itu, kalau dicermati secara saksama pandangan model ketiga ini merupakan kelahiran kembali dari bangunan teologi yang menamakan dirinya dengan natural teologi, yaitu sebuah bangunan teologi yang mendasarkan keyakinankeyakinannya tentang eksistensi Tuhan pada pemahaman tentang tealita dan fenomena alam.

Model teologi seperti itu menempuh cara yang dibangun oleh sains, sehingga Thomas F. Terrance berpendapat bahiva baik teologi maupun sains sama sama dibangun atas pengalaman manusia. Teologi sebenarnya menolong dan meyakinkan kita semua dalam menyelidiki alam semesta, sementara sains membantu kita dalam bal metode. Dengan begitu, metode ilmiah dan metode teologi sebenarnya mirip

${ }^{21}$ Fazlur Rahman (1980) Major Themes of the Qur'an, Chicago: Bibliotheca Islamica, p. 1. Juga - Fazlur Rahman, Islam (1979), Chicago: University of Chicago, p. 34.

${ }^{22}$ A.N. Whitehead (1929), Prosess and Reality, New York: The Free Press, p. .345. Konsep semacam ini sebenamya bukan hal yang baru, dalam dunia mistis Islam misalnya pemah dirintis dan dicetuskan oleh tokoh-tokoh sufi misalnya Ibnu Arabi atau al-Halaj. dengan konsep wihdatul wnjud (union mistic) patheisme). Sedangakan di dunia mistis Kristen Katholik misalnya pernah dicetuskan Meister Eckhart.

${ }^{23}$ Baqir, "Pengantar" dalam Barbour, Juru Bicara, p. 35. 
walau dalam bidang perhatian yang berbeda. ${ }^{24}$ Dari pernyataan Terrance di atas dapat dipahami bahwa sains dan agama (dalam hal ini teologi) bukannya berseberangan namun justru saling memberi kontribusi dan masukan positif bagaikan hubungan saudara kembar.

Mengingat kemunculan sains dan teologi sama-sama dibangun dari pengalaman manusia dan keduanya bisa saling memberi kontribusi, maka dari agama juga dinanti kontribusinya, khusunya dalam etika dan nilai-nilai spiritualitas. Etika sains ini diperlukan karena melihat netralitas sains banyak disalahgunakan oleh manusia yang mengatasnamakan sebagai penemu dan pengembang sains. Dari konteks ini maka persoalannya lebih terletak pada men bebind the sciences dan sangat tergantung dari pola mana manusianya mengikuti aliran filsafat. Konflik antara sains dan agama seperti disebut di atas juga terletak dari bangunan metafisikanya. Sains yang ternyata tidak netral secara normatif karena ia memang dibentuk oleh world view (pandangan dunia) tettentu. Dari ketidaknetralan semacam ini akhirnya sains banyak menyudutkan agama. U.paya para teolog untuk membangun "sains teistik" entah apa namanya (sains Kristen, sains Islam atau Islamisasi sains) rupanya memang dalam rangka mengkritisi aplikasi penyimpangan-penyimpangan sains dan bagaimana agama memberi masukan positif dan spiritualitas bagi sains.

Gagasan islamisasi sains misalnya, meski oleh sebagian orang dianggap bersifat apologis atau semacam pelarian ke tomantisme masa lalu (kejayaan peradaban Islam) rasanya juga tetap diperlukan dalam artian untuk terus membangkitkan kecintaan terhadap sains dan membendung kecenderungan destrukttif atas pemanfaatan sains. Meskipun demikian, orang seperti Abdus Salam tetap menyayangkan cara semacam itu. Karena selain kaum Muslimin memang harus mengejar ketertinggalan dalam sains dari dunia Barat juga posisi agama terpaksa harus diseret-seret untuk menjustifikasi penemuan-penemuan sains. Sains yang berjalan begitu cepat bahkan aplikasinya bisa liar di satu sisi dan agama sebagai landasan tekstual-normatif dan sebagai payung spiritualitas di sisi lain sudah semenstinya saling menyapa. Keyakinan agama (teologi) yang seting dianggap statis dan dogmatis seharusnya bisa selalu berjalan harmonis dan sehat berdampingan dengan sains meski kadang mengalami ketegangan antara keduanya. Pengupayaan kesenjangan budaya (cultural lag) dalam pengembangan sains dan agama dirasa sangat mendesak, mengingat bangunan epistemologis sains modern lebih didominasi oleh metafisika yang sekularistik, sehingga kecendrungan seperti tujuan yang bersifat materalistis dan hedonistis bisa semakin dikurangi dan dieliminir. Karena sejarah telah membuktikan bahwa berbagai krisis baik ekologi, sosial, budaya dan

${ }^{24}$ Linda Smith \& William Reaper (1991), Religious and Philosopbycal Ideas, Past and Present, London: Oxford, p. 186 
kemanusiaan dalam peradaban modern ini lebih banyak didòminasi oleh masyarakat modern yang berjiwa serakah dengan semangat memiliki secara material yang tidak pernah puas. ${ }^{25} \mathrm{Nafsu}$-nafsu semacam itu dalam prediksi al-Qur'an bila diliarkan dan dibiarkan terus bisa menajdi tuhan-tuhan baru (ittaba'a ilababu bawab) yang akhirnya juga akan mengalinieasi manusia dan merusak kenyamanan ekologis, baik sebagai mikrokosmos maupun keutuhan dan keseimbangan makrokosmos secara global.

Karena itu sains sangat perlu merengkuh metafisika agama. Sains yang dibangun atas kemampuan akal manusia dan agama yang berdasar wahyu Kitab Suci memang sejatinya berasal dari Tuhan, Dialah sebagai sumber ilmu dan kebenaran atau hikmah. Siapa yang diberi hikmah, maka ia telah memperoleh kebajikan yang banyak. (QS; 2; 269). Sains tanpa didampingi agama rasanya akan semakin mempercepat proses "kiamat" dalam artian semakin merusak keharmonisan ekologis maupun sosial. "Sains without religion is lame, religion without science is blind" kata seorang Einstein. Sains tanpa agama juga akan semakin membuktikan skeptisme para ilmuwan sendiri, karena sains seperti yang telah banyak kita saksikan hanya lebih mengandalkan kemampuan akal manusia. Fisikawan Werner Heinsberg juga pernah melontarkan dunia sains yang lebih didasari prinsip ketidakpastian (principle of uncertainty), bahwa pengetahuan tasional hanya mentok pada kemungkinan statistik sehingga secara teologis, ilmu semacam itu oleh manusia modern sudah dianggap "malampaui masa gunannya". Cibiran rasionalitas semacam ini juga telah menggugah kesadaran Theodore Roszak, dalam Where is Wasteland Ends, untuk mengingatkan manusia agar kembali ke kepekaan nilai-nilai agama dan meresapi spiritualitasnya.

Berkaitan dengan bagaimana seharusnya memberlakukan sains dan agama, maka posisi Abdus Salam sebagai abdullah dan khalifatullah hemat penulis sudah sangat islami karena sebagai muslim, dengan tafakkur dia terus melakukan penelitian dan pengembangan sains dan dengan tasykir dia telah memubuktikan upaya kerasnya dalam menjembatani ketertinggalannya di bidang sains. Hanya saja kaum muslimin masih kekurangan beberapa "Abdus Salam" baru di berbagai bidang sains. Karena muslim sejati adalah mereka yang dirinya telah diwarnai oleh tafakkur dan tasykir sebagai bagian dari cara Tuhan membentuk dan mewarnai spiritualitas hambanya (cf. QS: 2; 138).

\footnotetext{
${ }^{25}$ Keserakahan dan semangat memiliki atas kesenamgan dan kemewahan hal-hal yang bersifat wadag-material-duniawi itu dalam prespektif Islam bisa menjadi ancaman serius bagi masa depan manusia bila tidak diimbangi oleh nilai-nilai agama. Hal ini misalnya telah diperingatkan oleh QS : 102 , 1-2, "Bermewah-mewah telah melalaikan kamu, sampai kamu masuk ke liang kubur" juga dikuatkan hadist Nabi, "lau kana li ibni adam wadiyani min dzahabin, la'abtaghau tsalisan, la yamla'u jauf ibni adam illa alturab" (andaikata manusia itu mempunyai dua bukit emas, niscaya ia akan mengingintkan mempunyai yang ketiga dan tidak akan pernah mengenyangkan perut manusia kecuali (ia telab dikubur) tanab/mati)
} 
4. Mencari format ideal teo-ekologi dari hubungan agama dan sains

Dengan mempertimbangkan berbagai relasi dan percaturan agama dan sains di atas, setidaknya bisa digarisbawahi bahwa konsepsi Islam ideal sejak awal memang tidak memisahkan hubungan ilmu-ilmu agama (ulumuddin) dan ilmu umum atau sains, baik itu natural sciences atau social sciences. Hanya saja antata ideal dan cita-cita itu tidak mudah untuk diwujudkan. Sementara di dunia Barat modern memang telah terjadi pemisahan keduannya, meskipun dengan plus-minusnya telah mengantarkan Barat pada "kemenangan-kemenangan" peradabannya melalui kemajuan sains dan teknologi hingga akhirnya mereka mengakui bahwa pemisahan kedua wialyah ini justru semakin memperparah berbagai krisis. Padahal bila kita tengok sejarah peradaban ilmu (hadarab al-ilmiy) sebenarnya keduanya dibangun berdasarkan pengalaman realitas empiris kehidupan mnusia, baik itu ilmu-ilmu agama maupun ulmu-ilmu umum (natural and social sciences). Teologi Islam sebagai pijakan keyakinan, misalnya juga muncul dan dibangun dari pengalaman sejarah kehidupan manusia, yakni bagaimana mengangkat dan mengintepretasikan wilayah Tuhan, sebagai $R a b$ al-'alamin dalam keyakinan kehidupan manusia. ${ }^{26}$

Sementara kita sebagai bangsa yang secara teritorial-politis maupun pendidikan pernah terjajah oleh Barat, maka imbas pemisahan ilmu-ilmu agama (ulumuddin) dan ilmu-ilmu umum juga masih sangat terasa, terutama di PTAI (Perguruan Tinggi Agama Islam) dan lebih-lebih lagi di pesantren-pesantren. Imbas keterpisahan agama dan sains itu dalam konteks Indonesia - meski telah ada perubahan-perubahan masih sangat terasa hingga kini. Baru akhir-kahir ini, yakni priode ke-4 (1996 sampai sekarang) ternyata dikotomi dan apologi semacam itu tetap tidak bisa menjawab berbagai persoalan lingkungan dan sosial kemanusiaan secara empiris, sehingga Islamic Studies mau tidak mau mesti harus menjawab berbagai persoalan umat Islam khususnya dan persoalan kemanusian umumnya dengan mendialogkan atau mendiadigkan (istilah SH Nasr) secara terus menerus melalui bantuan berbagai perkembangan ilmu-ilmu sosial, humanities dan berbagai ilmu eksak (Iptek). Kerangka kerja semacam ini juga sudah mulai diterapkan oleh sejumlah pemikir muslim kontemporer di berbagai wilayah dunia. ${ }^{27}$

${ }^{26} \mathrm{Di}$ sini penulis tidak bermaksud menguraikan sejarah teologi Islam yang bermula dari persoalan politis, yakni semenjak peristiwa terbunuhnya Ustman bin Affan (finab al-kubra al-ula) yang berlanjut sampai ke pertempuran Siffin, peristiwa tahkim (arbirtase) sehingga memunculkan aliran-aliran teologis (Khawarij, Murji'ah dan Syi'ah) sampai akhirnya memunculkan berbagai persoalan dan pertanyaan teologis, seperti batas Islam-kafir, letak kemahakuasaan Tuhan yang menimbulkan persoalan free-will, dan predestination dalam posisi kehidupan manusia dan sebagainya. Untuk uraian lihat misalnya, Baedhowi (2003), "Rasionalisme dan Tradișionlaisme dalam Teologi Islam : Metajut Antara Pemikiran Mu'tazilah dan Asy'ariyyah", dalam Esensia, Vol. 4, No. 1, p. 86 dst. L. Gardet \& M.M. Annawati (1981), Introduction a la Theologie muselmane, Paris: Libraire Philosophque J. Vrin, p. 47 dst. Juga Harun Nasution (1973), Teologi islam Aliran-aliran Sejarah dan Perbandingan, Jakarta: Yayasan Penerbit UI, p. 7 dst. 
Penggunaan pendekatan dan metodologi semacam itu, bukan saja untuk menyambung kembali hubungan antara ilmu pengetahuan dan teknologi (IPTEK) yang telah terpisah bahkan seolah-olah tidak berinteraksi dari inti ajaran Islam (ilm al-qauliyab), namun juga untuk bisa memberikan respon positif, memberikan nilainilai normatif dan spiritual bagi pengembangan sains khususnya serta naungan etis bagi peradaban kontemporer pada umumnya. Dengan cara itu, agama (baca Islamic theologies) akan menjadi tidak asing lagi dengan berbagai isu-isu kontemporer (current issues), seperti, ekologi (persolan lingkungan), demokrasi, HAM, gender, plutalisme dan Iain sebagainya. ${ }^{28}$

Dari pengalaman historis semacam ini, fenomena berpapasannya budaya dan peradaban yang berbeda, terutama Islamic studies di satu sisi dan ilmu-ilmu umum di sisi lain memang telah menguji kaum beriman untuk tidak terhanyut dalam berbagai ketegangan emosional, lebih-lebih bersikap paroxial (kebanggaan semu dengan klaim kebenaran "teologis"nya sendiri tanpa mau menerima masukan dari epistemologi keilmuan lain). Kaum believers terutama dari para lulusan pesantren dan PTAI justru diharapkan menghargai paham-paham lain secara dewasa lebih-lebih bisa membangun dialog sains dan agama kemudian mengintegrasikannya sehingga tercipta pola kehidupan yang sehat, dinamis dan dalam nuansa keberagamaan yang tetap humanistis (bealtby-dinamic-bumanistic religiousity). Dengan membangun dialog agama dan sains, kaum agamawan meski berangkat dari keyakinan teologis sendiri juga diharapkan bersikap luwes dan bersikap “open ended" atas tafsiran-tafsiran teologisnya. Mereka akan memahami dari sisi perkembangan sains, bahwa kebenaran hasil temuan sains ternyata tidak bersifat monolistik dan tunggal, tidak betsifat absolut dan abadi. Sejarah perjalanan sains ternyata juga penuh dialektika dengan berbagai teori dan pendekatan. Jadi kesejarahan sains tampaknya memang dinamis, bahkan tidak sepi dari persoalan problematis ketika bersentuhan dengan pandangan keagamaan. Begitu

${ }^{27}$ Pergeseran dan perubahan yang disebut di atas dilihat Amin Abdullah begitu mencolok pada periode tahun sebelum 1950-an dan tahun 1951-1976-an. Pada priode pertama ilmu-ilmu_agama (ulumuddin) masih sangat eksklusif dan asing dengan ilmu-ilmu di luar dirinya. Sementara pada periode 1951-1976 meski Islamic Studies sudah mengenal ilmu-ilmu umum (sosial, humanities dan ilmu-ilmu alam) namun keterpisahan dam independensi kedua wilayah masih sangat dominan. Baru pada periode ke-3 (tahun 1976-1995) Islamic Studies sudah mulai merasakan berbagai keterbatasannya, namun inti dati ulumuddin tersebut tetap ingin memberlakukan ilmu-ilmu umum secara monodik (meminjam istilah SH Nast) degan memonopoli wilayah tafsir atau dengan mengklaim, "ma faradna fi al-Kitabi min sai' " $n$ " (QS; 6 : 38) bila memakai bahasa ideologis kaum apolog muslim. Lihat Amin Abdullah (2003) "New Horizon of Islamic Studies 'Throught Socio-Cultural Hermeneutics", dalam al-jami'ah, Vol. 41,No.1. p. 20-21. Juga Amin Abdullah (2001), Ta'wil al-Ilmiy Menuju ke Arah penafsiran Kitab Suci" dalam al-Jami'ab, Vol 39, No. 2, pp. 363-365.

${ }^{28} \mathrm{New}$. Horizon, Ibid., p. 16. khususnya ketetkaitan Islamic Studies dan ilmu-ilmu lainnya dalam menangani persoalan-persoalan kontemporer, yakni dalam ruang lingkup masyarakat multikultural dan multi relijius. 
juga kehidupan keberagamaan juga tidak steril dari berbagai problem kehidupan yang mengitari manusia, baik persoalan ekologis, sosial budaya dan kemanusiaan.

Porsi sains memang bukan untuk memberi panduan moral dan filsafat lebihlebih justifikasi teologis bagi kehidupan manusia, karena wilayah ini lebih merupakan wilayah agama. Sebaliknya Wahyu (baca Kitab Suci) meski banyak menginspirasikan untuk pengembangan sains namun juga tidak berpretensi memberikan kepintaran empiris dan teknis dalam menjawab berbagai persoalan ilmu alam, sejarah kebudayaan dan peradaban dalam kehidupan di kosmos ini. Dari kenyataan ini, hemat penulis memang perlu dipertajam analisis masing-masing dalam rangka pengembangan agama dan sains. Dengan cara ini, tetap dicari secara terus menerus dan dibangun formatformat hubungan ideal dan harmonis melalui pendekatan agama dan sains. Dengan hubungan timbal-balik, take and give secara harmonis, hemat penulis akan semakin mengkayakan wawasan dan mempertajam analasis masing-masing. Dengan cara itu pula, persoalan teologi bukan lagi sebagai wacana "hiburan" melainkan sebagai wacana dan keyakinan "progresif" yang diharapkan bisa mencerahkan dalam memecahkan problem kongkrit kehidupan manusia, seperti persoalan pengrusakan lingkungan, kebodohan, kemiskinan, kesehatan dan sebagainya.

Dari model-model hubungan sains dan agama di atas sudah seharusnya agama mulai mendekati pandangan-pandangan sains, paling tidak memanfaatkan hasil temuan sains untuk memperkaya wawasan dan mempertajam analisisnya. Lebih dari itu, kaum believers semestinya juga semakin memprtajam interpretasinnya atas Teks-teks Suci (Wahyu) dengan membenturkan pada realitas kongkrit kehidupan dan persoalan yang dihadapi manusia. Dari pengalaman semacam itu pula diharapkan bisa membentuk dan memanifestasikan diri kaum teolog pada esensi keberagamaan yang lebih esoteris dan membumi. Begitu juga para saintis juga tidak perlu memperkecil nilai-nilai agama, karena keduanya bisa saling mengisi nilai-nilai positif secara gradual. Keengganan dan kegamangan untuk mendialogkan nilai-nilai positif kedua wilayah agama dan sains justru akan semakin memperkecil arti penting kontribusi masing-masing. Agama akan bersifat defensif dan tertatih-tatih mengikuti kepesatan perkembangan sains, sementara sains akan semakin "menyombongkan diri" dengan pencapaian peradaban atas hasil-hasil temuan empirisnya meski di dalamnya kering dan haus akan nilai-nilai normatif dan spiritual. Pengupayaan dialog agama dan sains semacam ini yang dilihat Arkoun sebagai manifestasi Wahyu dalam artian sebagai proses panjang kebenaran dalam sejarah.

Dengan gambaran posisi wahyu semacam itu, konsep teologi (baca ilmu Kalam dalam Islam) bukan lagi berupa konsep-konsep yang hanya bersifat ideal-normatif, abstrak, steril dari ruang dan waktu serta bersifat deduktif, namun teologi Islam sudah seharusnya membenahi diri dan bersifat kritis terhadap tealitas-realitas empiris yang terjadi di sekiling kita, baik secara mikrokosmos maupun secara makrokosmos. 
Teologi Islam tradisional yang selama ini banyak menempatkan ayat-ayat Tuhan secara tekstual, reflektif, dan deduktif hendaknya dibenahi dan diarahkan pada refleksi induktif, difokuskan pada kesadaran kritis terhadap pengalaman-pengalaman dan problem kongkrit manusia saat ini. Teologi bukan lagi hanya mempersoalkan dan mempolemikkan penafsiran wilayah Tuhan yang dianggap miring ke wilayah teosentris atau antroposentris yang oleh L. Gardet lebih dianggap sebagai semacam pelarian, hiburan atau "apologi defensif", namun teologi Islam sudah semestinya memasuki wilayah progresif yang berorientasi pada realitas masa kini dan masa depan yang berkaitan dengan semua persoalan kehidupan manusia di alam raya ini.

Karena itu, bila teologi Islam tidak ingin kehilangan elan vital dan daya cengkramnya atas dunia modernitas sebagaimana yang telah dirasakan dan dialami dunia Barat, maka ia semestinya bisa mendinamisir melalui dua cara: Pertama, teologi Islam mesti bersifat "open ended", dan dinamis agar tidak terjerumus pada sikap konservatif dan defensif atas persoalan-persoalan manusia modern akibat perkembangan dan kemajuan sains dan teknologi, yang mana keduannya saat ini telah menjadi ideologi baru (meminjam istilah Herbamas). Keduanya (Iptek) telah mengubah bahkan mendikte sikap dan prilaku manusia modern, baik menuju yang positif seperti pemanfaatan Iptek untuk kemakmuran, kesejahteraan, dan kenyamanan hidup manusia maupun untuk maksud-maksud yang negatif dan destruktif seperti untuk kepentingan segelintir keolmpok dan individu, sehingga menimbulkan berbagai bala' dan bencana (crucial cricis), baik berbagai bencana ekologis maupun bencana kemanusiaan. Kedua Teologi Islam juga harus progresif dalam mengembangkan makna muslim dan taqwa miminjam konsep Fazlur Rahman. Muslim dalam artian posisi alam dan manusia pada hakekatnya tetap sama-sama tunduk pada Tuhan, Sang Penguasa jagad raya dan penuh kasih sayang. Hanya saja manusia dengan segala potensinya masih bisa mengingkari perintah-perintahNya, sedangkan alam tidak bisa mengingkari perintah-perintah-Nya. Sementata konsep taqwa, yang dalam teologi klasik sering didefinisikan dengan "mengikuti seluruh perintah-perintah-Nya dan menjauhi seluruh larangan-Nya" dalam kehidupn manusia modern juga berarti sebuah analog atas imperatif moral dalam pengembangan makna taqwa tersebut. Dengan begitu, muslim yang muttaqin sudah semestinya bukan saja sadar posisinya sebagai manusia dan hamba Tuhan (abdullab) yang tanggap atas kondisi lingkungan ekologis dan sosial-budayanya, namun juga sadar akan posisi dirinya sebagai pewaris dan pengembang potensi alam (baca kbalifatullab) dalam rangka pengoptimalan makna taqwa tersebut. Dengan begitu, dia bisa memberi kemanfaatan dan kontribusi maksimal atas potensi dirinya sebagai pewaris dan penjaga alam sekaligus bisa menaungi dengan payung moral bagi lingkungan ekologis dan sosial kemanusiaan.

Sebagai bagian dari teologi proses, teologi Islam juga tetap diharapkan bisa 
melerai dan mengharmoniskan dua kubu ekstrim epistemologi keilmuan, yakni antara sikap paroxial-teologis yang enggan menerima masukan dari temuan-temuan dari luar dirinya dan arogansi saintifis yang mengklaim semua sebagai hasil kepiawaian olah keilmuan manusia semata. Dalam teologi semacam ini peran Tuhan tidak dimaknai secara mutlak dan dominatif atas semua kejadian historis seperti pada teologi jabariah yang deterministis. Andil dan peran manusia juga menjadi bagian dari realitas historis. Karena teologi proses tetap sangat menghargai proses inisiatif Ilahi pada setiap entitas dan kehidupan secara tidak penuh dan mutlak. Di sini peran kebebasn manusia juga dihargai sebagai saham dan faktor pembentuk sejarah masa lalu. ${ }^{29}$

Dengan demikian teologi proses diharapkan tetap bisa menggabungkan tindakan Tuhan di dalam alam dan dalam pengalaman keagamaan manusia. Dengan cara ini kesadaran ekologis juga sangat terkait dari tindakan manusia. Katena itu semua kejadian historis tentang kerusakan ekologis juga sangat erat dari mental dan peran manusia yang destruktif, sebagaimana digambarakan oleh Qur'an, surat arRum 41, "Telah nyatalah kerusakan yang terjadi di muka bumi dan di lautan akibat ulah perbuatan manusia." Dari gambaran itu, kita juga bisa memahami bahwa teologi proses memang tetap menghargai Tuhan sebagai Sang Pencipta alam, namun dalam proses historis yang panjang keberadaan ekologis, dengan peran Tuhan sebagai Sang Pengendali dan Penguasa alam semesta juga berbagi dengan peran manusia. ${ }^{30}$

Dari uraian di atas, proses kerusakan ekologis tampaknya lebih dimulai dari ulah perbuatan manusia secara evolutif dan akumulatif yang dalam proses panjang akhirnya berimbas dan mengakibatkan bencana ekologis. Dengan demikian, teologi proses selain ingin menyeimbangkan unsur imanensi dan transendensi Tuhan juga sangat mendukung kelestarian dan penghargaan atas alam. Bahkan lebih jauh

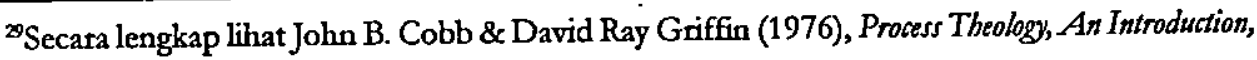
Philadelphia: Westminster Press, bab 3.

${ }^{30}$ Sebagai muslim, penulis dalam hal ini juga terinspirasi oleh tulisan al-Ghazali tentang titual "wudlu" (betsuci dari hadast kecil) sebelum orang menjalankan sholat. Karena titual ini selain bisa digunakan sebagai alternatif bydro-therapy (proses penyembuhan berbagai penyakit dengan ait). juga sebelum memasuki syarat wajibnya, seperti niat, membasuh muka, membasuh kedua tangan hingga siku, membasuh sebagian kepala dan membasuh kedua kaki, Islam juga mensunahkan untuk membaca do'a ketika awal membasuh kedua tangan (sebelum berkumur) dengan do'a, "Allabuma as'aluka yumna wa al-barakah wa naudzubika min al-sys'umi wa al-halakab" (Ya Allah saya memohon padaMu kebahagiaan/ keberuntungan dan berkah (bertambahnya nilai kebajikan) dan saya mohon perlindungan pada-Mu atas berbagai pebuatan yang menimbulkan kemalangan (aktivitas negatif-destruktif) dan kerusakan/ kehancuran). Dari proses ritual semacam ini, bila do'a itu saja memang dihayati, apalagi ditambah do'ado'a ketika menjalani urutan ritual wudhu lainnya, maka seorang muslim sejak awal sudah diingatkan untuk senantiasa berbuat hal yang positif-konstruktif dan dilarang berbuat secara negatif-destruktif sehingga menimbulkan berbagai kerusakan dan bencana, baik ekologi maupun bencana sosialkemanusiaan. Lihat, al-Ghazali, Abu Hamid (1346 H)lly'a' Ulumuddin, Vol. I, Mesir : Mustafa Bab alHalabi, p. 118. 
lagi menurut hemat penulis teologi proses berpotensi bisa membagi dan mengharmonikan hubungan antara wilayah Tuhan, manusia dan alam dengan pengembangan konsep mistisnya. Pengalaman semacam ini pernah dilakukan oleh tokoh sufi semisal Ibnu Arabiy (w. $261 \mathrm{H} / 875 \mathrm{M}$ ) dengan Wibdab al-wnjudnya atau mistikus Katholik, seperti Meister Eckhart (1260-1327M) dengan konsep penetheisme. Pandangan futuristis meteka penulis lihat sebagai pandangan yang holistik terhadap poosisi manusia dalam mikrokosmos (alam al-saghir) maupun makrokosmos (alam al-kabir), yakni upaya harmonisasi terhdadap ekologi dalam ranah maktokosmos dan dalam rangka memberikan sumbangan spiritualitas atas peradaban, yang mana semua entitas dan keberadaan alam dan manusia senantiasa berada di bawah payungpayung keteduhan ilahiyah. Dengan demikian pandangan mereka sebenarnya jauhjauh hari, baik secara eksplisit maupun implisit juga telah melampaui sikap praksis para pembela lingkungan yang menyerukan "back to nature" setelah adanya berbagai kesalahan kebijakan terhadap soal lingkungan, soal planologi dan kesengajaan pragmatis-hedonistis sehingga berujung pada krisis dan bencana alam yang semuanya diakibatkan oleh ulah, ambisi dan nafsu-nafsu keserakahan manusia.

\section{DAFTAR PUSTAKA}

Amin Abdullah (2003), "New Horizon of Islamic Studies Throught Socio-Cultural Hermeneutics" dalam al-jami'ah, Vol 41, No. 1, Journal of Islamic Studies, Yogyakarta: State of Islamic Studies (IAIN) Sunan Kalijaga (2001), Al-Ta'vil al-Ilmiy: Ke Arab Perubahan Penafsiran Kitab Suci, alJami'ah, Vol 39, No. 2, Journal of Islamic Studies, Yogyakarta: State of Islamic Studies (IAIN) Sunan Kalijaga.

Annawati, M.M. \& L. Gardet (1981), Introduction a la Theologie Muselmane, Paris: Libraire Philosophique J Vrin.

Arkoun, Mohammed (1991), Lectures $d u$ Coran, ed Tunis: Alif et. al. (1990), Liberte Religious dans Le Judaisme, le Cbristianisme et IIslam, Paris: CERF.

(1993), "Le Concept des Societes du Livre-Livre" dalam Interpreter, No. 3. Bachtiat. Amsal (1999), Filsafat Agama, Jakarta: Logos.

Baedhowi (2003), "Rasionalisme dan Tradisionalisme dalam Teologi Islam: Merajut Antara Mu'tazilah dan Asy'ariyyah" dalam Esensia, Vol. 4, No, 1, Journal Ilmu-

Ilmu Ushuluddin, Yogyakarta: IAIN Sunan Kalijaga.

Barbour, Ian G. (1966) Issues in Science and Religions., U.S.A: Prentice Hall Inc (2002) Juru Bicara Tuban Antara Sains dan Agama, Terj. E.R. Muhammad, Bandung: Mizan Pustaka 
Baucaille Maurice (1981), .Le Bible, le Coran et la Science, Paris: Saghers Caheers.A.F. (1983) Apa itu yang Dinamakan Ilmu, Jakarta: Hasta Mitra Carol, Denis (tt) What is Liberation Theology. Sydney: E.J. Dawywr Depag RI (1977) Al-Qur'an dan Terjemabannya, Jakarta: Depag Al-Ghazali, Abu Hamid (1346 H) Ibya' Ulumuddin, Vol. I, Mesir: Mustafa Bab alHalabi

Iqbal, Muhammad (1977) Reconstruction of Religious Thought in Islam, Lahore: M. Asraf.

John B. Cobb \& David Ray Griffin (1976) Process Theology. An Introduction, Philadelphia: Westminster Press.

Linda Smith \& William Reaper (1991) Religious and Philosophical Ideas. Past and Present, London: Oxford.

Ibnu Manzur (tt) Lisan al-Arab, tt. Juz. XVII, Bairut Dar Sadir, Muller. L. (1972) God and Reason: a Historical Approach to Philosohopical Theology, New York: The Macmillan Co.

Passemore, "Logical Positivisme" dalam Edward, ed., (1967) Encyclopedia of Philosopby, Vol V, London: Rotledge.

Rahman, Fazlur. (1981) Major Themes of the Qur'an, Chicago: Bibliotheca Islamica Rolston, Holmes (1987) Science and Religion, A Critical Survey, New York: Random Hause

Salam. Abdus, "Wawancara" dalam Tempo No. 400

Thomas S. Kuhn. (1962) The Structure of Scientific Religion, Chicago: Chicago University Press

Toffler. Alvin (1981) The Third Wave, London: Bantam Books Whitehead. N. Alfred (1929) Process and Reality, New York: The Mcmillan Co (1974) The Religion in Making, New York: New American Literary 